\title{
Government Formation and Cabinets
}

\author{
SONA N. GOLDER
}

\begin{abstract}
The government in a parliamentary (or semi-presidential) democracy refers to the prime minister and the other cabinet ministers, whereas the government in a presidential democracy refers to the president's cabinet. The members of the government cabinet determine national policy and arguably hold the most important political positions in their country. Most governments comprise two or more parties, which means that the government formation process requires coalition-building. During this process, party elites bargain over who gets which ministerial position and over policy; they can reach an agreement quickly and take office, or the bargaining can break down and take months to resolve. This essay discusses the different types of governments that can form as well as how they form in parliamentary, semi-presidential, and presidential regimes. Recent research on government formation and cabinets has introduced new theoretical arguments, and the implications of these arguments are being tested with new data and new statistical methods. For example, analyses of European democracies now include the post-communist Eastern countries (not only the Western ones), and more scholars are studying coalition governments in Latin America. Future research might include more work on cabinets in developing democracies in regions such as Africa and Asia, as well as analyses of the political and economic consequences of bargaining delays and the partisan composition of the government.
\end{abstract}

\section{INTRODUCTION}

What determines which party or parties enter the government cabinet? How are government ministries assigned to the politicians of different parties? Given that the parties that control government departments get to determine government policy, questions about who gets to have a seat at the cabinet table matter. What kinds of governments are likely to be stable, or be responsive to voters, or spend more? If the identity of the parties in a government cabinet affects government policy, and if government policies have consequences for citizens, then how the government formation process works and what kinds of governments might form are important questions.

The government formation process occurs differently in parliamentary or semi-presidential democracies compared with presidential ones, because the

Emerging Trends in the Social and Behavioral Sciences. Edited by Robert Scott and Stephen Kosslyn. (C) 2015 John Wiley \& Sons, Inc. ISBN 978-1-118-90077-2. 
relationship between the executive and legislative branches of the state is different across these regimes. Most of the political science literature on government formation and cabinets focuses on parliamentary and semi-presidential democracies, though, so we begin with these cases. A government in a parliamentary or semi-presidential democracy refers to the prime minister (the head of the government) and the other cabinet ministers, who are in charge of various policy areas such as education, finance, defense, or foreign affairs. The government in these democracies is said to be "responsible" to the legislature, which means that the legislature can dismiss the government from office any time a majority of legislators wants to do so. As long as the government retains the support of a majority of the legislators, it can stay in office (until the next required legislative election). The government sets policy for the country by sending legislation to be approved by the legislature or using its executive power to change regulations directly. If the party or parties in the cabinet control a majority of the seats in the legislature, then the government's proposed legislation will receive legislative approval easily most of the time. This is because legislators whose party is in government typically follow the instructions of their party leadership, who hold ministerial posts in the cabinet. Thus, in parliamentary democracies, the government cabinet tends to be the most important political actor.

The cabinet is usually the most important actor in a semi-presidential regime as well, though in some semi-presidential regimes, the president plays a predominant role rather than being a mere ceremonial head of state. The key difference between these two regimes is that in semi-presidential countries, the head of state (a president) is elected by the voters. In parliamentary systems, the head of state is not elected by the voters but is, rather, an unelected monarch or a president elected by the members of the legislature. For this essay, the relevant aspect of a semi-presidential government is that it is responsible to the legislature, like governments in parliamentary systems (Amorim Neto \& Strøm, 2006).

In a parliamentary democracy such as the United Kingdom, in which a single party typically wins a majority of the legislative seats, the formation of the government is a straightforward process. The leader of the winning party presents a list of the proposed members of government, mainly well-known members of the winning party, to the head of state (the Queen) and she approves it. In the legislative elections in the United Kingdom in 2010, however, no single party won a majority of the legislative seats. This legislative outcome was highly unusual for the United Kingdom, but is similar to what happens in most parliamentary democracies on a regular basis. After that election, the party leaders of the three largest parties explored the possibilities of various coalition governments that would control a majority of the legislative seats. Ultimately, a coalition government formed between two 
parties, the Conservatives and the Liberal Democrats, and elites from both parties received ministerial positions. The leader of the larger party became the new prime minister. The scenario that followed the 2010 elections in the United Kingdom, with party leaders from various parties bargaining over the formation of a new government, is a common one in parliamentary democracies across the globe. How the government formation process works, how long it takes, and which government ultimately takes office are questions of interest to politicians, the media, economic actors, and the voters alike.

In presidential democracies, unlike parliamentary or semi-presidential ones, the president is the head of state and the head of government, and the president's government cannot be removed from office by the legislature even if a majority in the legislature would dearly love to do so. The fact that the legislature in a presidential democracy cannot dismiss the government, which means that these governments can stay in office without the support of a legislative majority, has profound implications for the government formation process in presidential versus parliamentary democracies. The president, rather than the cabinet, tends to be the focus of attention in presidential democracies, though the president's government still plays an important role in determining policy (Cheibub, Przeworski, \& Saiegh, 2004).

\section{FOUNDATIONAL RESEARCH}

Governments in Parliamentary, Semi-Presidential, and Presidential Regimes

The government in the United Kingdom depends on the support, or the approval, of a majority of the members of the House of Commons to remain in office. If a majority of the legislators want to, they can vote the government out of office with a "vote of no confidence" (i.e., they agree that they no longer have confidence in the current government's ability to carry out its duties). Following a successful vote of no confidence, the government will resign; this is followed by either a new government taking office or new legislative elections. A vote of no confidence can be called any time some of the legislators decide that they do not approve of the government's policy and want a change of government; the vote of no confidence is an ordinary procedure in a parliamentary democracy. Most studies about government formation and cabinets focus on countries that allow votes of no confidence (Laver \& Schofield, 1998). In other words, most studies focus on parliamentary and semi-presidential governments. In both of these regimes, the head of government is the prime minister. In contrast, in presidential democracies, as mentioned earlier, the president is both the head of state and the head of government, and the cabinet cannot be removed by the legislature using ordinary legislative procedures. 
Countries that allow the legislature to use a vote of no confidence to remove a government are more likely to have governments composed of parties that control a majority of the legislative seats than are presidential democracies. In addition, politicians in countries where votes of no confidence can be used by the legislature find it more important to form a government that can maintain a majority over the course of the legislative term. The incentive to find and maintain a majority in the legislature affects all aspects of cabinets in parliamentary and semi-presidential democracies, from which parties get to be in the government, which (or how many) ministerial positions they receive, how long the government takes to form, and how stable it is once in office.

\section{TYPES OF GOVERNMENTS}

Political scientists commonly assume that politicians care about both policy and office (Laver \& Schofield, 1998). With respect to office, becoming a government minister is one of the highest achievements a politician can accomplish. Such positions are highly sought after both because of the power and prestige associated with such a position and because members of the government have a strong influence over policy. If a party is in the government cabinet, then some members of the party's leadership will be given ministerial portfolios, where a "portfolio" is the policy area for which a minister is responsible. For example, if a member of government is given the education portfolio, he or she will be in charge of the civil servants who work for the education ministry and will be expected to formulate new education policies while the government is in office. In addition to appreciating the intrinsic value of holding office, the new ministers try to influence the government's policy in ways that reflect their own party's preferences in the hopes that these policies will be rewarded by the party's voters. Most bills are introduced by the government, rather than by members of parliament; government-sponsored bills also pass the legislature at higher rates than member-sponsored bills. Thus, government ministers can have an important influence over policy.

Governments that control a majority of the legislative seats will have an easier time having their policy passed and staying in power than will governments that control only a minority of the legislative seats. This is because minority governments must be tolerated by a majority of the legislators if they are to stay in office, but they cannot automatically count on the support of a majority in the legislature when they put their legislation forward. Instead, minority governments need to negotiate legislative majorities ahead of time, and might put together different majorities to pass different kinds of legislation. For example, a minority government comprising a Social Democratic party might pass some kinds of legislation with center-right parties but pass 
other kinds of legislation with the help of a Communist party. Majority governments have an easier time getting their legislation passed than minority governments do, because the party leaders who are ministers in the government are usually able to count on their party members in the legislature to vote to support government bills. This is one reason why most of the theories about government formation usually assume that actors want to form majority governments rather than minority ones.

An implication of the assumption that politicians value office-in this case, cabinet ministries, or portfolios-is that we should see as few parties as possible being included in the government. Adding parties to government, above and beyond what is needed to control a majority in the legislature, can be expensive in terms of office benefits. Each government party gets at least one ministerial portfolio. Further, the share of ministerial portfolios going to each party is typically fairly proportional to the share of legislative seats a party brings to the government's total; this proportional relationship is known as Gamson's law (Warwick \& Druckman, 2006). Thus, the politician in charge of forming the government, the formateur, should not include parties that are not actually needed for building a majority if he or she wants to keep as many portfolios as possible for his or her own party. The expectation, based on a long tradition of scholarship on government formation (especially studies that use formal models, or game theory, in their arguments), is that a "minimal winning coalition" should form-this is a government in which the cabinet controls a majority of the legislative seats and in which every party in the government is needed to maintain that majority. This means that if a single party won a majority of the legislative seats, we should see a single-party majority government form, and if no party won a majority, then we should see a minimal winning coalition government form.

In the real world, we often see minimal winning coalitions form. However, it is not unusual to see either minority or surplus governments form, even if they are less common than the minimal winning coalition governments. Minority governments tend to form when no clear majority alternative exists. For example, if a fairly large (albeit not majority) center-left party is in government, with an extreme left party on one side of the policy space and several right wing parties that cannot agree on policy issues on the other side, then that single-party minority government can be quite stable in office. In a situation like this one, the opposition parties are unlikely to reach a consensus on bringing the government down, even though they constitute a majority in the legislature. Minority governments are also more likely to form when opposition parties have a larger role in policy-making within the legislature, so that a party does not need to be in government to influence policy. This can occur in countries where bills can be easily amended in legislative committees, and members from both government and opposition parties routinely 
have a role in revising the legislation. Surplus governments, where at least one government party is not needed to control a legislative majority but is given ministerial portfolios anyway, sometimes form when parties are bound by a pre-electoral agreement to go into government together. This explains some of the cases of majority parties forming a coalition with a small electoral alliance partner even if they do not need the additional seats to control a majority. Surplus governments also form when a government will need a surplus majority to pass certain kinds of legislation (say, a constitutional change) during the next legislative period, or when the prime ministerial party wants to prevent smaller coalition partners from being able to bring the government down if they disagree over policy.

\section{The Government Formation Process}

Many of the foundational studies of the government formation process emphasize parliamentary democracies, largely in Western Europe, but their insights apply to all parliamentary democracies, and generalize to semi-presidential ones as well. These works rely on empirical, case-based studies as well as game theory arguments (e.g., the 1998 account of multiparty government by Michael Laver and Norman Schofield) and address important aspects of the life cycle of governments (e.g., the 2008 volume edited by Kaare Strøm, Wolfgang C. Müller, and Torbjörn Bergman).

Composition of Parties in Government. If any party has a majority of the seats in the legislature, that party can form a government on its own and the leader of the majority party nearly always becomes the prime minister. In most parliamentary democracies, though, no single party wins a majority of the seats. (Not having a majority party can have important policy consequences; according to an analysis of government spending by Kathleen Bawn and Frances Rosenbluth (2006), coalition governments spend more and have a larger public sector than single party majority governments do.) In a couple of countries (Greece and Bulgaria), the sequence for appointing a formateur to form a government is specified in the constitution: a formateur is chosen from the largest legislative party first, and if this formateur fails to put a government together, then a new formateur is chosen from the second largest party, and so on, until a government is formed or new elections are called. In other countries, no such formal rule exists. Typically, there is a norm that the leader of the largest party, or the leaders of large parties generally, will take the lead in bargaining over a new government. Which leader will be successful is not always easy to predict when looking at the election results (even if the media has already proclaimed the largest party to be the "winner" of the 
election). In principle, any party could go into government with any other party or parties. In practice, though, some parties are ideologically incompatible, and are thus unlikely to become partners in any government cabinet. For example, parties with very different policy preferences over economic or social issues would have a hard time compromising on a joint government policy, and might find themselves punished by their electorates in the next elections because of intra-cabinet conflicts. A center-left party is unlikely to form a government with an extreme right party because they have incompatible policy preferences, and the center-left party presumably has more compatible partners with which to form a government. Parties that have enough common ground to develop a coalition policy will be able to go into government together if they can gain the support of a legislative majority to do so.

In presidential regimes, the president is the formateur and the president's party is always represented in the cabinet. If the president's party has a majority of seats in the legislature, then the president does not need to consider a coalition cabinet. In countries where the president can use executive decrees to change policy, the president is less reliant on building legislative majorities to pass legislation, and thus will be less likely to invite other parties into the cabinet. In countries where the president needs legislative majorities to make policy changes and where the president's party controls only a minority of the seats, the president is likely to form coalition governments that look much like those found in parliamentary democracies (Cheibub et al., 2004). As Marisa Kellam (2014) shows, though, these minority presidents have more flexibility than their prime ministerial counterparts when it comes to choosing coalition partners and shifting their governing strategies during their term in office.

Bargaining Delays. After a legislative election in a parliamentary democracy, the identity of the next government might be fairly obvious to all of the actors concerned. For example, in the United Kingdom, if either the Labour Party or the Conservative Party wins a majority of the legislative seats, then that party will swiftly approach the Queen with a list of cabinet members for her (pro forma) approval, and take office immediately. In cases where no party wins a majority of the seats, the identity of the next government is not necessarily clear. If parties compete as an electoral alliance, and jointly win a majority of the seats, then a government comprising those parties will also be quick to form. Even without an electoral alliance, if an ideologically compatible group of parties could control a majority of the seats, then agreeing to form a new coalition government together might occur swiftly, particularly if the 
parties have prior experience working together. Some legislative elections do not result in a swift government formation processes, however.

If no single party or electoral alliance wins a majority, and the parties that were elected to the legislature cannot easily find common ground, then the process of putting a new cabinet together can be long and drawn out, with first one formateur and then another trying, and failing, to manage the government formation process successfully. For a long time, the most well-known example of a government formation delay was the one that followed the Dutch elections in 1977, when it took 208 days for a new government to take office. This record was broken, first in Iraq in 2010 when it took 8 months for a government to form after legislative elections there, and then in Belgium when the government formation process following legislative elections in 2010 lasted for an astounding 18 months.

In all three of these lengthy government formation processes, specific contextual factors contributed to the bargaining delays. Yet all three examples have commonalities, too, that fit with our general understanding of what factors lead to long, drawn-out government formation processes. For example, in each case, the legislature was fragmented into many smallor medium-sized parties, and these parties had ideological goals that often appeared to be incompatible with one another. The complexity of the bargaining environment was high, because there were many different combinations of parties that could have entered into government together. In all three examples, the government formation opportunity followed a legislative election. Elections introduce more uncertainty than would be present if a government were forming without an election, following a government resignation. This is because the seat shares of the parties in the legislature nearly always change after an election, and sometimes, the identities of the party leaders change as well. A party leader might resign if his or her party did poorly in the election, for example. Thus, when sitting down to negotiate, the actors are not certain what policy or office deals would be acceptable to their potential government partners. No actor wants to make an overly generous offer, though, so haggling over office and policy can drag out, as parties gain information from the offers and counter-offers that are put forward. Bargaining complexity, along with uncertainty about what offers would be acceptable, can lead to long periods in which no new government can take office (Golder, 2010).

During the bargaining period, the outgoing government remains in office in a caretaker capacity, and is expected to maintain existing government policy without implementing new policies. In Western Europe, the average bargaining delay is close to a month. If a government takes a few weeks to form, having a caretaker government is unlikely to pose significant problems (barring a crisis that occurs during the government formation process). However, 
a government formation process that continues for half a year (or more) can lead to serious complications, as decisions that ought to be made are postponed until a new government with an official mandate takes office. Lengthy bargaining delays do not occur in presidential democracies, where a president elected for a fixed term is automatically the formateur and can make take-it-or-leave-it offers to other parties, if he or she chooses to invite other parties into the government in the first place.

Portfolio Allocation. When party leaders come to an agreement about which parties will constitute the new government, they also need to decide how many portfolios, or ministerial positions, each party will receive, as well as which portfolios go to which party. As mentioned earlier, the norm (often referred to as Gamson's law) is that each government party will get a share of the government portfolios that approximates the share of legislative seats that it contributes to the government's total set of legislative seats. If two parties form a government, and one party has 40 members in the legislature and the other party has 120 members in the legislature, then together they control 160 legislators. The smaller party contributes one-fourth of the legislators to the government's total, and should get one-fourth of the portfolios, whereas the larger party contributes three-fourths of the legislators and should get three-fourths of the portfolios. The party of the formateur nearly always gets the prime ministerial portfolio. If a Green party is in the government, it normally receives the environmental portfolio; in other cases, it is less obvious which party will get which portfolio, though if a party has a strong interest in a particular policy area, then this will be considered when bargaining over portfolios.

In practice, portfolios do not get allocated in a perfectly proportional manner. Although the relationship between a party's share of the government's legislative seats and the party's share of the ministerial portfolios is very strong, there is normally a slight advantage for the smaller governmental parties. That is, the largest parties - the ones that tend to be given the position of formateur in the first place-typically get less than their "fair share" of the portfolios, whereas their smaller partners get more. Paul Warwick and James Druckman (2006) show that the pattern of a fairly proportional allocation of ministerial portfolios, with a bias that favors small parties, is consistent across many decades in Western European democracies. The story is different in presidential regimes, though, where the president does not allocate portfolios so generously to coalition partners, and where more portfolios are given to nonpartisan ministers - that is, to people who are not connected with a party in the legislature. In presidential regimes, such ministers are either chosen for technical expertise or personal loyalty (a friend of the 
president). Although nonpartisan ministers are found in parliamentary and semi-presidential democracies as well, they are less frequent because they do not help the cabinet maintain legislative support.

\section{CUTTING-EDGE RESEARCH}

Early political science research on government formation was largely based on democracies in Western Europe, and much of what we know about government formation and cabinets comes from the experiences of these countries. However, in recent years, this has changed. The transition to democracy of most of the Eastern European countries around 1990 provides an important source of new data about the government formation process. Scholars can test hypotheses from theories that might have been developed with Western European examples in mind on completely different cases. The passage of time and the emergence of new parliamentary and semi-presidential democracies (both within and outside of Europe) provide analysts with valuable new information. Scholars have also begun using subnational government coalitions (regional or local) to test their hypotheses on new cases (Bäck, 2003).

The literature on coalition formation has a strong tradition of formal theory, particularly with the use of game theoretic bargaining models. The original formal models of government formation typically contained three parties and generated outcomes in which a minimal winning coalition would form immediately, with most of the share of the office benefits allocated to the larger (formateur) party. More recent work has aimed at matching the real world more closely (see, e.g., Laver, de Marchi, \& Mutlu, 2011). Some newer models have been able to produce minority coalitions as well as surplus ones, bargaining delays, and a more proportional allocation of portfolios that approximates the bias in favor of small parties that we see in the real world. The recent models have generated new implications to be tested as well.

In addition to new data and new theoretical arguments, scholars have been developing methods for more appropriately testing theories about government formation. As statistical methods become more advanced (and at the same time easier to use), researchers have been finding more appropriate methods for analyzing their data. For example, scholars use statistical techniques originally designed by medical researchers to analyze the duration of events-such an approach is used to examine which factors affect the length of bargaining delays. More recently, scholars have borrowed from other literatures (voting behavior, transportation economics, etc.) to find new ways of testing hypotheses about which prime ministerial party 
gets chosen out of the set of all possible parties, or which government coalition gets chosen out of the set of all possible coalitions, or how to examine both of these choices together. Combining statistical methods that allow researchers to answer new questions, with more data from democracies around the world, should allow researchers to continue to generate novel insights into the government formation process.

The original research agenda, developed by scholars focused on governments in the parliamentary democracies of Western Europe, expanded first to encompass semi-presidential regimes and then presidential ones. Most of the literature still focuses on parliamentary and semi-presidential regimes, but work on government formation in presidential systems has been increasing rapidly. Presidential parties often control only a minority of the legislative seats, which means that presidents, when forming their cabinets, often build coalition governments. As mentioned earlier, some of the dynamics of government formation and legislative-executive relations are quite different in presidential regimes compared to parliamentary or semi-presidential ones; however, some of the dynamics are surprisingly similar. Scholars are only beginning to compare across all three regimes, taking seriously the variation within and across them.

\section{KEY ISSUES FOR FUTURE RESEARCH}

In future research, scholars will be able to exploit the new data and new methods to broaden the scope of the questions they ask, as well as revisit some of the "conventional wisdom" to see if it still holds up (or under which conditions it holds up). The emphasis in the study of cabinets has long been on parliamentary democracies, and on the making and breaking of governments-the moment when they form as well as when and why they end. However, who gets into government or how stable that government is matters because of what governments do. We generally assume that the type and partisan composition of a government affects what kind of policy agenda it pursues and how successful it will be in enacting its agenda. Yet few studies link policy outcomes to governments, or examine how legislators interact with government ministers to produce policy, or whether bargaining delays have pernicious economic outcomes. These issues are at the heart of why governments matter. Such research is challenging, though, because examining government policy (or legislative behavior) of many governments over time and across countries requires large-scale data-gathering projects. Dealing with the different languages, different institutional rules and the different historical and other contextual features that are relevant to each country pose a challenge for researchers. 
Contributions from qualitative and quantitative scholars, along with pure formal theory contributions, are all relevant for this research agenda.

Going forward, as more studies compare across presidential, parliamentary, and semi-presidential democracies, we will hopefully see studies of previously ignored or understudied regions. We know little about government formation processes in developing democracies-who gets in, how long does it take, who gets what, and so on. Thus far, researchers using a cross-national approach to answering these kinds of questions have done so mostly in the context of advanced industrialized democracies. As scholars begin to explore a wider set of countries, however, they may need to modify their theories because some of the characteristics of the government formation process familiar to scholars of Western Europe, say, are not necessarily relevant elsewhere. For example, most models of government formation treat parties as if they are unitary actors. The reason for this is that European parties tend to enter and exit government cabinets as a single unit, and most European parties are organized in such a way that the party leaders can exercise tight discipline over their members. Thus, if a party enters government, the party leaders will have some ministerial portfolios and they can also, by and large, tell their legislative members how to vote. Legislators who disobey directives from party elites are likely to be ejected from the party, or at the very least find it difficult to be reelected to the legislature. This scenario does not fit all countries, however (Samuels \& Shugart, 2010). Government formation processes in some countries are focused sharply around an influential leader, often the president, rather than determined by the distribution of parties in the legislature.

In fact, our existing theories might be mainly applicable to countries with particular types of party systems. What happens if we relax some of the assumptions in our existing theories? How does the government formation process work in countries without disciplined parties, or with parties that are built around presidential candidates, and so may change from election to election? How are portfolios allocated if regional or ethnic groups are the relevant groups to be brought into a support coalition, or if patronage is the relevant factor, rather than parties that are arrayed on the left-right ideological dimension that dominates the policy landscape in Western Europe? Few scholars have examined government formation in the developing democracies in Africa, for example, but it seems reasonable to think that the standard models based on Western Europe might not adequately explain the dynamics of legislative-executive relations in many African countries. The limits of our existing theories ought to push researchers to consider more carefully how much existing arguments rely upon features of Western European countries that may not be applicable elsewhere. 


\section{REFERENCES}

Amorim Neto, O. \& Strøm, K. (2006). Breaking the parliamentary chain of delegation: Presidents and non-partisan cabinet members in European democracies. British Journal of Political Science 36, 619-643. http://dx.doi.org/10.1017/ S0007123406000330

Bäck, H. (2003). Explaining and predicting coalition outcomes: Conclusions from studying data on local coalitions. European Journal of Political Research, 42, 441-472. doi:10.1111/1475-6765.00092

Bawn, K., \& Rosenbluth, F. (2006). Short versus long coalitions: Electoral accountability and the size of the public sector. American Journal of Political Science, 50, 251-265. doi:10.1111/j.1540-5907.2006.00182.x

Cheibub, J., Przeworski, A., \& Saiegh, S. (2004). Government coalitions and legislative success under presidentialism and parliamentarism. British Journal of Political Science, 34, 565-587. doi:10.1017/S0007123404000195

Golder, S. (2010). Bargaining delays in the government formation process. Comparative Political Studies, 43, 3-32. doi:10.1177/0010414009341714

Kellam, M. (2014). Parties for hire: How particularistic parties influence presidents' governing strategies. Party Politics. doi:10.1177/1354068813487109

Laver, M., de Marchi, S., \& Mutlu, H. (2011). Negotiation in legislatures over government formation. Public Choice, 147, 285-304. doi:10.1007/s11127-010-9627-4

Laver, M., \& Schofield, N. (1998). Multiparty governments: The politics of coalitions in Europe. Ann Arbor: University of Michigan Press.

Samuels, S., \& Shugart, M. (2010). Presidents, parties, and prime ministers: How the separation of powers affects party organization and behavior. New York, NY: Cambridge University Press.

Strøm, K., Müller, W., \& Bergman, T. (2008). Cabinets and coalition bargaining: The democratic life cycle in Western Europe. New York, NY: Oxford University Press.

Warwick, P., \& Druckman, J. (2006). The portfolio allocation paradox: An investigation into the nature of a very strong but puzzling relationship. European Journal of Political Research, 45, 635-665. doi:10.1111/j.1475-6765.2006.00632.x

\section{FURTHER READING}

Bassi, A. (2013). A model of endogenous government formation. American Journal of Political Science, 57, 777-793. doi:10.1111/ajps.12031

Glasgow, G., Golder, M., \& Golder, S. (2011). Who 'Wins'? Determining the party of the prime minister. American Journal of Political Science, 55, 937-954. doi:10.1111/j.1540-5907.2011.00524.x

Golder, M., Golder, S., \& Siegel, D. (2012). Modeling the institutional foundation of parliamentary government formation. Journal of Politics, 72, 427-445. doi:10.1017/S0022381611001654

Krook, M., \& O'Brien, D. (2012). All the president's men? The numbers and portfolio allocations of female cabinet ministers. Journal of Politics, 74, 840-855. doi:10.1017/S0022381612000382 
Martínez-Gallardo, C. (2012). Out of the cabinet: What drives defections from the government in presidential systems? Comparative Political Studies, 45, 62-90. doi:10.1177/0010414011421306

Müller, W., \& Strøm, K. (Eds.) (2000). Coalition governments in Western Europe. Oxford, England: Oxford University Press.

Strøm, K., Müller, W., \& Bergman, T. (Eds.) (2004). Delegation and accountability in parliamentary democracies. Oxford, England: Oxford University Press.

\section{SONA N. GOLDER SHORT BIOGRAPHY}

Sona N. Golder is an Associate Professor in the Political Science Department at the Pennsylvania State University. Her general research interests are on political institutions. She has written and coauthored books and articles on the causes and consequences of pre-electoral coalitions (The Logic of Pre-Electoral Coalition Formation, 2006), government stability (in the European Journal of Political Research, 2010, with Courtenay R. Conrad), and portfolio allocation (in the British Journal of Political Science, 2014, with Jacquelyn A. Thomas). She is currently working on government formation in Europe; she and various coauthors have published some articles (see, e.g., Further Readings), and she is now working on a book manuscript (with Garrett Glasgow) on this topic. She has also coauthored a comparative politics textbook (Principles of Comparative Politics, 2nd Edition, 2012, with William Roberts Clark and Matt Golder).

Personal webpage: https://files.nyu.edu/sln202/public/

Curriculum vitae: https:/ files.nyu.edu/sln202/public/Vitae.pdf.

\section{RELATED ESSAYS}

Party Organizations' Electioneering Arms Race (Political Science), John H. Aldrich and Jeffrey D. Grynaviski

Economic Models of Voting (Political Science), Ian G. Anson and Timothy Hellwig

The Underrepresentation of Women in Elective Office (Political Science), Sarah F. Anzia

Political Ideologies (Political Science), Edward G. Carmines and Nicholas J.

D'Amico

Misinformation and How to Correct It (Psychology), John Cook et al.

Political Advertising (Political Science), Erika Franklin Fowler

Women Running for Office (Political Science), Jennifer L. Lawless

Participatory Governance (Political Science), Stephanie L. McNulty and Brian Wampler

Gender and Women's Influence in Public Settings (Political Science), Tali Mendelberg et al. 
Money in Politics (Political Science), Jeffrey Milyo

Feminists in Power (Sociology), Ann Orloff and Talia Schiff

Electoral Authoritarianism (Political Science), Andreas Schedler

Leadership (Anthropology), Adrienne Tecza and Dominic Johnson

Constitutionalism (Political Science), Keith E. Whittington

Gender and Work (Sociology), Christine L. Williams and Megan Tobias Neely 